\title{
Fly Ash-Based Geopolymer Mortar Incorporating Bottom Ash
}

\author{
Djwantoro HARDJITO (Corresponding author) \\ Dept. of Civil Engineering \\ Petra Christian University \\ Surabaya, Indonesia \\ E-mail: djwantoro.h@gmail.com \\ Shaw Shen, FUNG \\ Dept. of Civil and Construction Engineering \\ School of Engineering and Science \\ Curtin University of Technology \\ Miri, Sarawak, Malaysia
}

\begin{abstract}
This paper presents the results of study on effect of various parameters on mechanical properties of fly ash-based geopolymer mortar with bottom ash as partial or full replacement for sand. Compressive strength of samples with $10 \%$ bottom ash (BA) was comparable to those with only sand. Further increase in bottom ash content decreased the compressive strength. However, the reverse tendency occurred after exposing the samples to $1000^{\circ} \mathrm{C}$ for 24 hours.
\end{abstract}

Keywords: Fly ash, Bottom ash, Geopolymer mortar, Compressive strength, Thermal exposure, Workability

\section{Introduction}

Portland cement is widely used in concrete industry since many decades ago, however it releases green house gases, i.e. carbon dioxide $\left(\mathrm{CO}_{2}\right)$, into the atmosphere during its manufacture (Malhotra, 2002b). Geopolymer technology is one of the new technologies attempted to reduce the use of Portland cement in concrete. Fly ash reacts with alkaline solutions to form a cementitious material; fly ash based geopolymer; which does not emit carbon dioxide into the atmosphere. In this project, bottom ash is considered as partial- or full-replacement for sand as fine aggregate in the geopolymer mortar. To date, bottom ash from Sejingkat Coal Fired Power Station in Kuching, Sarawak, Malaysia, has not been utilised yet.

Fly ash and bottom ash are residues from the combustion of coal. Fly ash is captured in the chimney while bottom ash is collected from the bottom of the furnace from the coal fired power plant. Furthermore, the particles of fly ash are very fine whereas bottom ash has much larger particle size, which is about the size of sand but more porous. In Sejingkat Coal Fired Power Station, fly ash and bottom ash are disposed off into an $81,000 \mathrm{~m}^{2}$ area, $2.4 \mathrm{~m}$ deep ash pond situated beside the power station (Tsen, 2008). In fact, currently there are two ash ponds with one of them has been fully utilized.

Fly ash based geopolymer with bottom ash gives emphasis in reducing carbon dioxide emission and in recycling fly ash and bottom ash. Since fly ash and bottom ash are the waste products of coal fired power plant, this research can lead to the awareness of sustainable development to the society. This is very advisable in sustainable developments to reduce $\mathrm{CO}_{2}$ emission and to recycle the waste materials. At present time, there is limited information on the influence of parameters on geopolymer available, especially geopolymer with bottom ash as the fine aggregate. As a result, study on the effect of different parameters on the fly ash based geopolymer with bottom ash as sand replacement is needed. In addition, this research can provide additional information and to further introduce geopolymer to concrete industry. 


\section{Literature Review}

Geopolymers are amorphous to semi-crystalline three-dimensional alumino-silicate polymers similar to zeolites. Geopolymers consist of polymeric silicon-oxygen-aluminium framework with silicon and aluminium tetrahedral alternately linked together in three direction by sharing all the oxygen atoms. The negative charge created by aluminium is balanced by the presence of positive ions such as $\mathrm{Na}^{+}, \mathrm{K}^{+}$, and $\mathrm{Ca}^{+}$. The empirical formula of these mineral polymers is $\mathrm{M}_{n}\left[-\left(\mathrm{SiO}_{2}\right)_{z}-\mathrm{AlO}_{2}\right]_{n} \cdot w \mathrm{H}_{2} \mathrm{O}$, where $\mathrm{M}$ is an alkali cation such as potassium or sodium, the symbol - indicates the presence of a bond, $z$ is 1, 2 or 3, and $n$ is the degree of polymerisation (Davidovits, 1994).

Geopolymers are environmental friendly materials which do not emit green house gases during polymerisation process. Besides, they need only moderate energy to produce. Geopolymers are made from source materials with silicon (Si) and Aluminium (Al) content, thus they can be made using fly ash, waste-product of coal-fired power station, as the source materials (Hardjito, Wallah, Sumajouw, \& Rangan, 2004a). Furthermore, geopolymer possesses excellent mechanical properties which does not dissolve in acidic solution and does not generate any hazardous alkali-aggregate reaction even with alkali content as high as $9.2 \%$ (Davidovits, 1999).

Optimum curing temperature of $60^{\circ} \mathrm{C}$ was suggested for the study of the geopolymer mortar with small $50 \mathrm{~mm}$ cube size. This suggestion is based on the fact that smaller cube is having higher surface area-to-volume ratio compared to larger cube. Which, as a result, the smaller cube is more vulnerable to the high curing temperature and would experience loss of moisture during curing compared with the larger samples (P. Chindaprasirt, Chareerat, \& Sirivivatnanon, 2006).

Álvarez-Ayuso et al. (2007) suggested that the optimum curing time would be 48 hours. Curing time showed commonly a positive effect to the compressive strength of geopolymer mortar, and this effect is much more noticeable at the optimum curing temperature, $80^{\circ} \mathrm{C}$, suggested by them (Álvarez-Ayuso, et al., 2007). Besides, Swanepoel and Strydom (2002) also agreed that the optimum curing time for a geopolymer mortar would be 48 hours or 2 days.

On the other hand, Hardjito et al. (2005) mentioned that increase in the curing time would also assist the increase in compressive strength which also agreed by other researcher. But, a curing time further than 48 hours does not increase compressive strength significantly (Hardjito, Wallah, Sumajouw, \& Rangan, 2004b; Hardjito, et al., 2005).

Increase of concentration of $\mathrm{NaOH}$ increases the compressive strength of geopolymer. This is mainly because of the concentration of $\mathrm{NaOH}$ solution is directly affecting the dissolution of the metakaolinite particulates, which affecting the formation of the geopolymer framework. To have strong inter-molecular bonding strength of the geopolymer, more reactive bond for the monomer is needed. This can be achieved by a better dissolving ability to metakaolinite particulates. To obtain a better dissolving ability to metakaolinite particulates, a higher concentration of $\mathrm{NaOH}$ solution is required (Wang, Li, \& Yan, 2005). However, in Chindaprasirt, Chareerat, and Sirivivatnanon (2007) research, the effect of concentration of $\mathrm{NaOH}$ on compressive strength was not clear. The concentration of $\mathrm{NaOH}$ of 10, 15, $20 \mathrm{M}$ were used, and the average compressive strengths were 48.4, 49.1 and 50.2 MPa respectively (P. Chindaprasirt, et al., 2006).

Geopolymer with fluidized bed combustion bottom ash (FBC-BA) experienced a decrease in compressive strength with the increase of the content of FBC-BA in the prepared specimens. Increasing the content of FBC-BA to about $50 \%$ caused the decrease of the compressive strength (Slavik, Bednarik, Vondruska, \& Nemec, 2008).

For the case of normal fly ash concrete incorporating bottom ash as replacement for fly ash, the increase in bottom ash content decreased the compressive strength. Furthermore, most of the compressive strengths were gained after 28 days. The pozzolanic reactivity of bottom ash could be improved with adequate grinding and use it as sand replacement in concrete, where sand is more expensive than bottom ash (Kula, Olgun, Erdogan, \& Sevinc, 2001).

Water retainability is defined as the amount of water absorbed into the pores and adsorbed on the rough surface of bottom ash. The usual collapsed-cone test method to determine the saturated surface dry condition was not achievable for bottom ash. Therefore an alternative method based on the gravitational removal of excess water from the bottom ash was introduced to determine the water retainability of bottom ash (Kasemchaisiri \& Tangtermsirikul, 2007).

The compressive strength of fly ash-based geopolymer mortar exposed to $400{ }^{\circ} \mathrm{C}$ increased by about $100 \%$ compared to samples without any exposure to high thermal environment. Geopolymer possesses high thermal resistance up to $800{ }^{\circ} \mathrm{C}$ without showing any decrease in compressive strength (Tsen, 2008). However, after exposure to thermal exposure above $800{ }^{\circ} \mathrm{C}$, compressive strength of geopolymer prepared using sodium based alkaline activator rapidly declined (Bakharev, 2006). In fact, geopolymer mortar does not experience release water in an explosive manner or dehydrate to a powder like OPC. In brief, geopolymer mortar is able to resist thermal exposure up to $1000{ }^{\circ} \mathrm{C}$ (Gourley \& Johnson, 2005). 


\section{Materials and Experimental Details}

\subsection{Materials}

Fly ash, Class F under ASTM C 618, used in this experiment was obtained from Sejingkat Coal-Fired Power Station. The coal used in the power station is mainly supplied from the coal mine in Merit Pila, Kapit, Sarawak, Malaysia. Specific surface area and particle density of the fly ash are $1.51 \mathrm{~m}^{2} / \mathrm{ml}$ and $2370 \mathrm{~kg} / \mathrm{m}^{3}$ respectively. The chemical composition of the fly ash, as determined by X-Ray Fluorescence (XRF) analysis is shown in Table 1. According to the chemical composition as shown in Table 1, the mass ratio of $\mathrm{SiO}_{2}$ to $\mathrm{Al}_{2} \mathrm{O}_{3}$ of the fly ash is 2.34 .

Similarly, bottom ash used in this experiment was obtained from Sejingkat Coal-Fired Power Station. The specific gravity of the bottom ash is 2.23 and fineness modulus (FM) is 0.14 . Suitable moisture content (22\%) of bottom ash was prepared in advance and stored for prior use. Sand used in this experiment is in saturated surface-dry (SSD) condition. Fineness modulus (FM) and specific gravity are 1.44 and 2.67 respectively. These data reveal that the particle size of the sand is rather small with FM only 1.44, moreover the particle size of the bottom ash is even smaller than sand (FM of 0.14).

Mixture of Potassium Silicate $\left(\mathrm{K}_{2} \mathrm{SiO}_{3}\right)$ solution and Potassium Hydroxide $(\mathrm{KOH})$ solution were chosen as the alkaline activator. This was because the type of alkaline activator that contained only hydroxides revealed in a lower reaction rate than when soluble silicates were also used as the activators (Palomo, Grutzeck, \& Blanco, 1999). Furthermore, potassium-based activator was chosen because it produced a better strength compared to sodium-based activator (Xu \& Van Deventer, 2000).

\subsection{Experimental Programme and Mixture Proportion}

In order to analyse the effect of content of bottom ash on compressive strength, R1 was chosen as the reference sample. On the other hand, R2 was chosen as the reference sample in the experiment on the effect of different curing temperature, concentration of $\mathrm{KOH}$ solution and $\mathrm{K}_{2} \mathrm{SiO}_{3}$-to-KOH solution ratio by mass on compressive strength.

Furthermore, mixtures R1, R2, 1-7, 12, 13, 15 and 17 were subjected to thermal exposure of $400{ }^{\circ} \mathrm{C}, 700{ }^{\circ} \mathrm{C}$ and $1000{ }^{\circ} \mathrm{C}$ on the sixth day and compressive strength test was conducted on the next day. Seventh days compressive strength of samples with no thermal exposure was taken as the reference for the compressive strength of samples subjected to thermal exposure. The experimental programme is shown in Table 2.

Fine aggregate to fly ash ratio by mass of 2.75 was attempted to design the required quantity of all geopolymer mortars (2006). Besides that, $\mathrm{K}_{2} \mathrm{SiO}_{3}$ solution and $\mathrm{KOH}$ solution were weighted according to the required proportion. The mixture proportion is shown in Table 3.

\subsection{Mixing, Casting, Curing and Thermal Exposure}

The mixing and casting of the geopolymer mortar was referred to method implemented by Tsen (2008). Raw materials, i.e. fly ash and fine aggregate, were dry mixed in the mixer at the paddle speed of $140 \pm 5 \mathrm{r} / \mathrm{min}$ for 2 minutes. At the same time, alkaline activator with mixture of $\mathrm{K}_{2} \mathrm{SiO}_{3}$ solution and $\mathrm{KOH}$ solution were premixed in another flask. After that, the alkaline activator was mixed with the raw materials in the mixer for another 10 minutes.

Then, the fresh geopolymer mortar was placed in the $50 \mathrm{~mm}$ x $50 \mathrm{~mm}$ x $50 \mathrm{~mm}$ specimen moulds in two layers. Each layer was compacted by a tamper for 20 times. After the casting of the geopolymer mortars in the specimen moulds, the mixtures were vibrated using vibrating table for another 2 minutes to remove air voids. All the mixing and casting were done in an air-conditioned room of temperature approximately at $25^{\circ} \mathrm{C}$.

Next, all the mixtures were cured in an oven without delay time at the specific curing temperature for 24 hours. Samples were demoulded after the curing process in the oven and cured in room temperature until the testing age.

Samples that subjected to thermal exposure were exposed in a furnace on the sixth day at an incremental rate of $10{ }^{\circ} \mathrm{C} / \mathrm{min}$ from room temperature. The desired temperature was maintained for 3 hours before the samples were allowed to cool naturally to room temperature in the furnace. Then the samples were tested on the next day.

\subsection{Testing}

Three $50 \mathrm{~mm}$ x $50 \mathrm{~mm}$ x $50 \mathrm{~mm}$ samples were tested for each data. Load rate $90 \mathrm{kN} / \mathrm{min}$ was applied on the sample. The maximum load shown by the testing machine was recorded and the compressive strength of the sample was calculated.

Workability was measured by the flow of the fresh geopolymer mortar on flow table for mortar. First, flow mould was placed in the middle of the flow table. A layer of fresh geopolymer mortar about $25 \mathrm{~mm}$ thick was placed in the mould and tamped with the tampers for 20 times. This was repeated for the second layer. Then the mould was lifted away and immediately the table was dropped from a height of $12.7 \pm 0.13 \mathrm{~mm}$ for 25 times in $15 \mathrm{sec}$. Finally, the diameter of the geopolymer mortar along the four lines scribed in the table top was recorded. Then, the flow expressed as a percentage of the original base diameter was calculated as follow. First, 'A', the average of the four readings, in millimeters, minus 
the original inside base diameter was calculated. Next, 'A' was divided by the original inside base diameter and multiplied by 100 .

\section{Results and Discussions}

\subsection{Compressive Strength}

\section{(1) Content of Bottom Ash}

Mixture R1, R2, 12-17 were made to investigate the effect of content of bottom ash on compressive strength and Fig. 1 shows the results. The compressive strength of the bottom ash geopolymer mortar decreases with the increase of bottom ash content. This could, probably, be due to the water released into the mixture by the bottom ash (Andrade, Rocha, \& Cheriaf, 2008). Water can be highly retained, in term of absorption and adsorption, into and onto the bottom ash due to the high porosity and irregular surface (Kasemchaisiri \& Tangtermsirikul, 2007). With the amount of the water increased in the mortar, the compressive strength of the geopolymer mortar eventually decreases. On the other hand, the higher porosity of the bottom ash also caused the lower compressive strength to the geopolymer mortar (Prinya Chindaprasirt, Jaturapitakkul, Chalee, \& Rattanasak, 2008). However, $10 \%$ of river sand can be replaced by bottom ash as fine aggregates in fly ash-based geopolymer mortar without any significant decrease in its compressive strength.

\section{(2) Curing Temperature}

Mixture R2 and 1-3 were made to analyse the effect of curing temperature on compressive strength and Fig. 2 shows the results. A higher curing temperature will increase the compressive strength of the geopolymer mortar. This is because energy required for dissolution of fly ash is an endothermic process (Álvarez-Ayuso, et al., 2007). However, the samples will normally experience the loss of moisture content with high curing temperature whereby geopolymerisation requires the presence of moisture to achieve a good compressive strength (P. Chindaprasirt, et al., 2006).

\section{(3) Concentration of $\mathrm{KOH}$ Solution}

Mixture R2 and 4-7 were made to study the effect of concentration of KOH solution on compressive strength and Fig. 3 shows the results. The higher the concentration of the $\mathrm{KOH}$ solution, the higher the compressive strength is. This is mainly because the concentration of $\mathrm{KOH}$ solution is directly affecting the dissolution of fly ash which affects the formation of the geopolymer framework (Wang, et al., 2005). However, the compressive strength resulted in this research is slightly lower than compressive strength in research conducted by Tsen (2008). This is most probably due to the incorporation of bottom ash in the sample.

\section{(4) $\mathrm{K} 2 \mathrm{SiO} 3$-to-KOH Solution Ratio by Mass}

Mixture R2 and 8-11 were made to study the effect of $\mathrm{K}_{2} \mathrm{SiO}_{3}$-to- $\mathrm{KOH}$ solution ratio by mass on compressive strength and Fig. 4 shows the results. Compressive strength of samples with $\mathrm{K}_{2} \mathrm{SiO}_{3}$-to-KOH solution ratio by mass of 0.4 to 1.0 are noticeably higher than those with $\mathrm{K}_{2} \mathrm{SiO}_{3}$-to- $\mathrm{KOH}$ solution ratio by mass of 1.5 and 2.5 which is similar to research by Tsen (2008). Again, similar to this researcher's research, the optimum $\mathrm{K}_{2} \mathrm{SiO}_{3}$-to- $\mathrm{KOH}$ solution ratio by mass for compressive strength was 1.0. However, this was rather unexpected. In research conducted by Hardjito et al. (2004b) on the low calcium fly ash reacted by sodium based alkaline solution showed that the higher of silicate-to-hydroxide solution ratio by mass resulted in higher compressive strength.

\subsection{Thermal Resistance}

Mixture R1, R2, 12, 13, 15 and 17 were made to study the effect of content of bottom ash on compressive strength. From Fig. 5, the highest compressive strength is achieved by the samples exposed to $400{ }^{\circ} \mathrm{C}$ which also shown in Tsen (2008) report. Geopolymer possesses high thermal resistance up to $700{ }^{\circ} \mathrm{C}$ without any significant decrease in compressive strength. Furthermore, samples exposed to $1000{ }^{\circ} \mathrm{C}$ is experiencing decrease in compressive strength as reported also by other researcher (Bakharev, 2006). In fact, similar to other researcher, these samples do not experience release water in an explosive manner or dehydrate to a powder like OPC (Gourley \& Johnson, 2005).

The compressive strength increases with the increase of bottom ash content in samples exposed to $1000{ }^{\circ} \mathrm{C}$. Undeniable, this trend is different compared to the samples that are not exposed to any high thermal environment or exposed to temperature lower than $700{ }^{\circ} \mathrm{C}$ which can be observed from Fig. 5. In brief, samples with lower bottom ash content ( $0 \%-25 \%)$ decreases in compressive strength after exposure to elevated temperature of $400{ }^{\circ} \mathrm{C}$ to $1000{ }^{\circ} \mathrm{C}$, meanwhile samples with higher bottom ash content $(50 \%-100 \%)$ increases in compressive strength after exposure to elevated temperature of $400{ }^{\circ} \mathrm{C}$ to $1000{ }^{\circ} \mathrm{C}$ which can be observed from Fig. 6 . This is probably due to higher temperature, especially at $1000^{\circ} \mathrm{C}$, activated the bottom ash, and indeed increased the compressive strength of the samples. Thus, further research on the characteristic of bottom ash in high temperature is needed.

\subsection{Workability}

Workability of fresh geopolymer mortar of mixture R1, R2 and 12-17 were studied in this section. Effect of bottom ash content on workability is shown in Fig. 7. First, workability measured by flow of fresh geopolymer mortar increases 
with the increase of bottom ash content in the mixture. This is because water retained by the bottom ash will be released into the mixture during the mixing (Andrade, et al., 2008). This additional water will increase the workability of the fresh mortar. However, with the amount of bottom ash in fresh geopolymer mortar more than $75 \%$, workability decreases. This is most probably due to the angular shape and rough texture causing high inter-particle friction of the bottom ash although the water content increased in the mixture (Kasemchaisiri \& Tangtermsirikul, 2007). The more the content of bottom ash in fresh mortar, the higher the inter-particle friction is.

\section{Conclusions}

(1). Increase of bottom ash content decreases the compressive strength of geopolymer mortar. However, compressive strength of geopolymer mortar with $10 \%$ of bottom ash is comparable to geopolymer mortar without bottom ash.

(2). Increase of curing temperature increases the compressive strength of the geopolymer mortar.

(3). Increase in concentration of $\mathrm{KOH}$ solution also increases the compressive strength of geopolymer mortar.

(4). The optimum $\mathrm{K}_{2} \mathrm{SiO}_{3}$-to- $\mathrm{KOH}$ solution ratio by mass is about 1.0.

(5). Geopolymer mortar with lower bottom ash content $(0 \%-25 \%)$ decreases in compressive strength after exposure to elevated temperature from $400{ }^{\circ} \mathrm{C}$ to $1000{ }^{\circ} \mathrm{C}$, meanwhile geopolymer mortar with higher bottom ash content (50\%-100\%) increases in compressive strength after exposure to elevated temperature of $400{ }^{\circ} \mathrm{C}$ to $1000{ }^{\circ} \mathrm{C}$.

(6). Increase of bottom ash content increases workability of fresh geopolymer mortar but it decreases with bottom ash content more than $75 \%$.

\section{References}

Álvarez-Ayuso, E., Querol, X., Plana, F., Alastuey, A., Moreno, N., Izquierdo, M., et al. (2007). Environmental, physical and structural characterisation of geopolymer matrixes synthesised from coal (co-)combustion fly ashes. Journal of Hazardous Materials, 154(1-3), 175-183.

Andrade, L. B., Rocha, J. C., \& Cheriaf, M. (2009). Influence of coal bottom ash as fine aggregate on fresh properties of concrete. Construction and Building Materials, 23(2), 609-614.

Bakharev, T. (2006). Thermal behaviour of geopolymers prepared using class F fly ash and elevated temperature curing. Cement and Concrete Research, 36(6), 1134-1147.

Chindaprasirt, P., Chareerat, T., \& Sirivivatnanon, V. (2006). Workability and strength of coarse high calcium fly ash geopolymer. Cement and Concrete Composites, 29(3), 224-229.

Chindaprasirt, P., Jaturapitakkul, C., Chalee, W., \& Rattanasak, U. (2008). Comparative study on the characteristics of fly ash and bottom ash geopolymers. Waste Management, 29(2), 539-543.

Davidovits, J. (1994). High-Alkali Cements for 21st Century Concretes. Special Publication, 144, 383-398.

Davidovits, J. (1999, June 30-July 2, 1999). Chemistry of Geopolymeric Systems, Terminology. Paper presented at the Geopolymer '99 International Conference, Saint-Quentin, France.

Gourley, J. T., \& Johnson, G. B. (2005, June 29-July 1, 2005). Develoments in geopolymer precast concrete. Paper presented at the World Congress Geopolymer 2005, Saint-Quentin, France.

Hardjito, D., Wallah, S. E., Sumajouw, D. M. J., \& Rangan, B. V. (2004a). Properties of Geopolymer Concrete with Fly Ash as Source Material: Effect of Mixture Composition. Paper presented at the Seventh CANMET/ACI International Conference on Recent Advances in Concrete Technology Las Vegas, Nevada, U.S.A.

Hardjito, D., Wallah, S. E., Sumajouw, D. M. J., \& Rangan, B. V. (2004b). On the Development of Fly Ash-Based Geopolymer Concrete. ACI Materials Journal, 101(6), 467-472.

Hardjito, D., Wallah, S. E., Sumajouw, D. M. J., \& Rangan, B. V. (2005). Fly ash-based geopolymer concrete. Australian Journal of Structural Engineering, 6(1), 77-84.

Kasemchaisiri, R., \& Tangtermsirikul, S. (2007). A method to determine water retainability of porous fine aggregate for design and quality control of fresh concrete. Construction and Building Materials, 21(6), 1322-1334.

Kula, I., Olgun, A., Erdogan, Y., \& Sevinc, V. (2001). Effects of colemanite waste, cool bottom ash, and fly ash on the properties of cement. Cement and Concrete Research, 31(3), 491-494.

Malhotra, V. M. (2002b). Introduction: Sustainable Development and Concrete Technology. Concrete International, 24(7), 22.

Palomo, A., Grutzeck, M. W., \& Blanco, M. T. (1999). Alkali-activated fly ashes: A cement for the future. Cement and Concrete Research, 29(8), 1323-1329.

Slavik, R., Bednarik, V., Vondruska, M., \& Nemec, A. (2008). Preparation of geopolymer from fluidized bed 
combustion bottom ash. Journal of Materials Processing Technology, 200(1-3), 265-270.

Swanepoel, J. C., \& Strydom, C. A. (2002). Utilisation of fly ash in a geopolymeric material. Applied Geochemistry, 17(8), 1143-1148.

Tsen, M. Z. (2008). The properties of fly ash-based geopolymer mortar with potassium-based alkaline reactor. Unpublished BEng diss., Curtin University of Technology

Wang, H., Li, H., \& Yan, F. (2005). Synthesis and mechanical properties of metakaolinite-based geopolymer. Colloids and Surfaces A: Physicochemical and Engineering Aspects, 268(1-3), 1-6.

$\mathrm{Xu}$, H., \& Van Deventer, J. S. J. (2000). The geopolymerisation of alumino-silicate minerals. International Journal of Mineral Processing, 59(3), 247-266.

Table 1. Chemical Composition of Fly Ash as Determined by XRF

\begin{tabular}{|c|c|}
\hline Oxides & \% mass \\
\hline $\mathrm{SiO}_{2}$ & 58.0 \\
$\mathrm{Al}_{2} \mathrm{O}_{3}$ & 24.8 \\
$\mathrm{Fe}_{2} \mathrm{O}_{3}$ & 7.17 \\
$\mathrm{~K}_{2} \mathrm{O}$ & 3.14 \\
$\mathrm{CaO}$ & 2.40 \\
$\mathrm{MgO}$ & 1.95 \\
$\mathrm{TiO}_{2}$ & 1.05 \\
$\mathrm{P}_{2} \mathrm{O}_{5}$ & 0.34 \\
$\mathrm{Na}_{2} \mathrm{O}$ & 0.30 \\
$\mathrm{MnO}_{\mathrm{SO}}$ & 0.18 \\
$\mathrm{LOI}$ & 0.08 \\
\hline
\end{tabular}

Table 2. Experimental Programme

\begin{tabular}{|c|c|c|c|c|c|}
\hline Mixture No. & $\begin{array}{c}\text { Curing Temp } \\
\left({ }^{\circ} \mathrm{C}\right)\end{array}$ & $\begin{array}{l}\text { Conc. of } \\
\text { KOH (M) }\end{array}$ & $\begin{array}{c}\mathrm{K}_{2} \mathrm{SiO}_{3} \text {-to-KOH Ratio by } \\
\text { Mass }\end{array}$ & $\begin{array}{l}\text { Bottom Ash } \\
\text { Content (\%) }\end{array}$ & $\begin{array}{c}\text { Sand Content } \\
(\%)\end{array}$ \\
\hline R1 & 60 & 12 & 1.0 & 0 & 100 \\
\hline $\mathrm{R} 2$ & 60 & 12 & 1.0 & 10 & 90 \\
\hline 1 & 50 & 12 & 1.0 & 10 & 90 \\
\hline 2 & 70 & 12 & 1.0 & 10 & 90 \\
\hline 3 & 80 & 12 & 1.0 & 10 & 90 \\
\hline 4 & 60 & 6 & 1.0 & 10 & 90 \\
\hline 5 & 60 & 8 & 1.0 & 10 & 90 \\
\hline 6 & 60 & 10 & 1.0 & 10 & 90 \\
\hline 7 & 60 & 14 & 1.0 & 10 & 90 \\
\hline $8 *$ & 60 & 12 & 0.4 & 10 & 90 \\
\hline $9 *$ & 60 & 12 & 0.8 & 10 & 90 \\
\hline $10^{*}$ & 60 & 12 & 1.5 & 10 & 90 \\
\hline $11 *$ & 60 & 12 & 2.5 & 10 & 90 \\
\hline 12 & 60 & 12 & 1.0 & 25 & 75 \\
\hline 13 & 60 & 12 & 1.0 & 50 & 50 \\
\hline $14^{*}$ & 60 & 12 & 1.0 & 65 & 35 \\
\hline 15 & 60 & 12 & 1.0 & 75 & 25 \\
\hline $16^{*}$ & 60 & 12 & 1.0 & 90 & 10 \\
\hline 17 & 60 & 12 & 1.0 & 100 & 0 \\
\hline
\end{tabular}

*Mixtures do not subject to thermal exposure. 
Table 3. Mixture Proportion

\begin{tabular}{|c|c|c|c|c|c|}
\hline \multirow{2}{*}{ Mixture No. } & \multicolumn{2}{|c|}{$\begin{array}{c}\text { Fine Aggregate } \\
\end{array}$} & \multirow{2}{*}{ Fly Ash $\left(\mathrm{kg} / \mathrm{m}^{3}\right)$} & \multirow{2}{*}{$\mathrm{K}_{2} \mathrm{SiO}_{3}\left(\mathrm{~kg} / \mathrm{m}^{3}\right)$} & \multirow{2}{*}{ KOH $\left(\mathrm{kg} / \mathrm{m}^{3}\right)$} \\
\hline & Bottom Ash $\left(\mathrm{kg} / \mathrm{m}^{3}\right)$ & Sand $\left(\mathrm{kg} / \mathrm{m}^{3}\right)$ & & & \\
\hline R1 & 0 & 1382 & 503 & 127.5 & 127.5 \\
\hline $\mathrm{R} 2$ & 138 & 1244 & 503 & 127.5 & 127.5 \\
\hline 1 & 138 & 1244 & 503 & 127.5 & 127.5 \\
\hline 2 & 138 & 1244 & 503 & 127.5 & 127.5 \\
\hline 3 & 138 & 1244 & 503 & 127.5 & 127.5 \\
\hline 4 & 138 & 1244 & 503 & 127.5 & 127.5 \\
\hline 5 & 138 & 1244 & 503 & 127.5 & 127.5 \\
\hline 6 & 138 & 1244 & 503 & 127.5 & 127.5 \\
\hline 7 & 138 & 1244 & 503 & 127.5 & 127.5 \\
\hline $8^{*}$ & 138 & 1244 & 503 & 72.9 & 182.1 \\
\hline $9^{*}$ & 138 & 1244 & 503 & 113.3 & 141.7 \\
\hline $10 *$ & 138 & 1244 & 503 & 153.0 & 102.0 \\
\hline $11^{*}$ & 138 & 1244 & 503 & 182.1 & 72.9 \\
\hline 12 & 346 & 1036 & 503 & 127.5 & 127.5 \\
\hline 13 & 691 & 691 & 503 & 127.5 & 127.5 \\
\hline $14 *$ & 898 & 484 & 503 & 127.5 & 127.5 \\
\hline 15 & 1036 & 346 & 503 & 127.5 & 127.5 \\
\hline $16^{*}$ & 1244 & 138 & 503 & 127.5 & 127.5 \\
\hline 17 & 1382 & 0 & 503 & 127.5 & 127.5 \\
\hline
\end{tabular}

*Mixtures do not subject to thermal exposure.

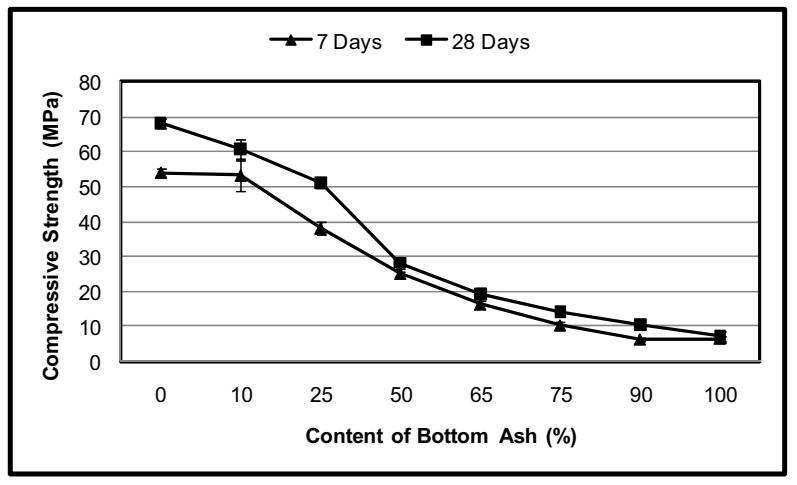

Figure 1. Effect of Content of Bottom Ash on Compressive Strength

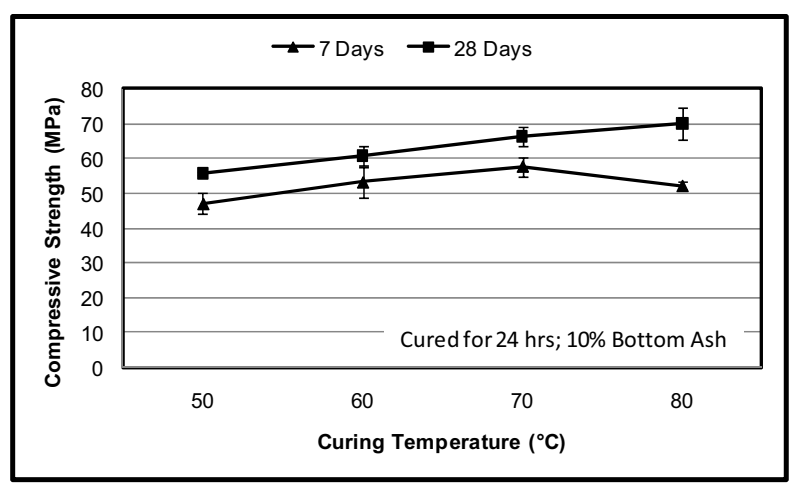

Figure 2. Effect of Curing Temperature on Compressive Strength 


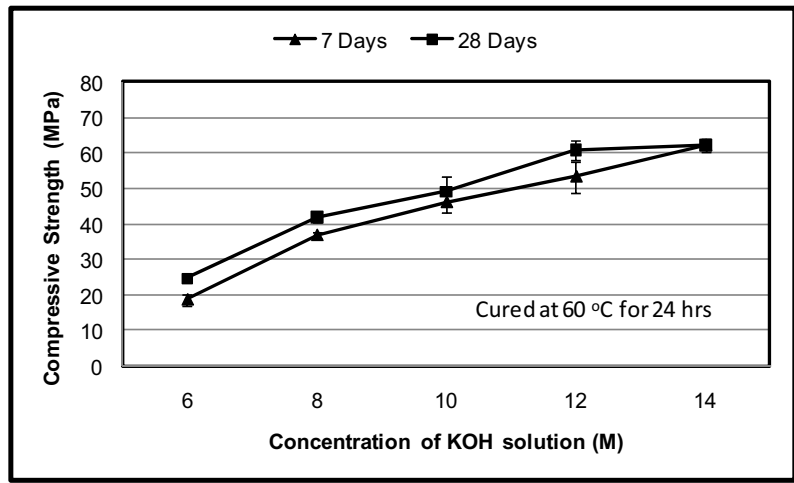

Figure 3. Effect of Concentration of KOH Solution on Compressive Strength

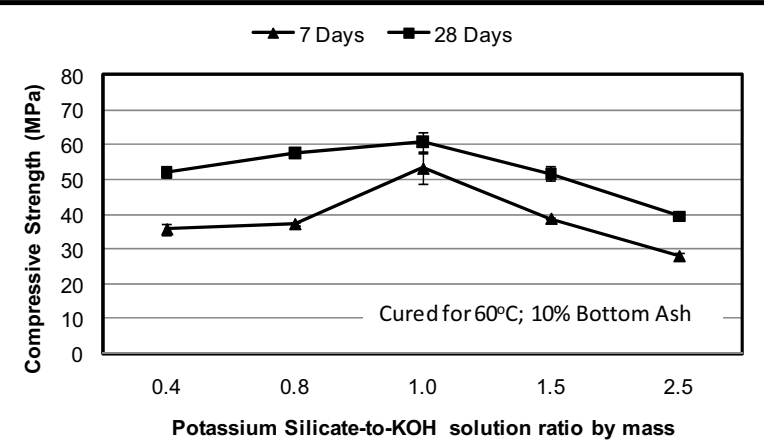

Figure 4. Effect of $\mathrm{K}_{2} \mathrm{SiO}_{3}$-to-KOH Solution Ratio by Mass on Compressive Strength

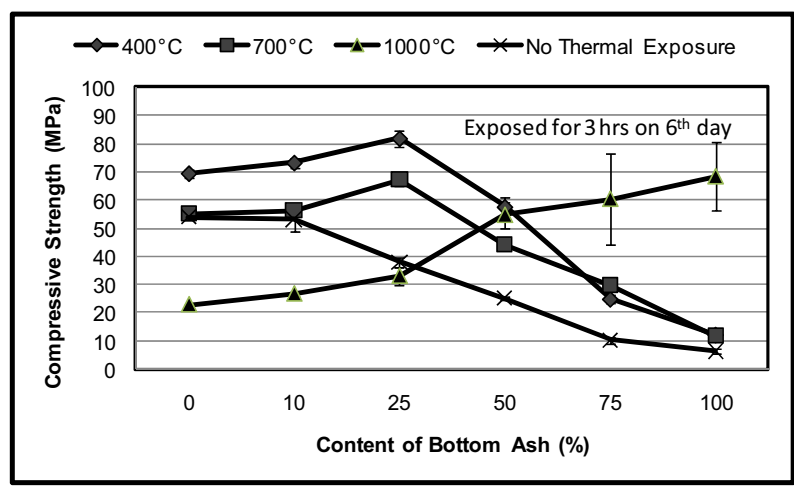

Figure 5. Effect of Content of Bottom Ash on Compressive Strength after Thermal Exposure

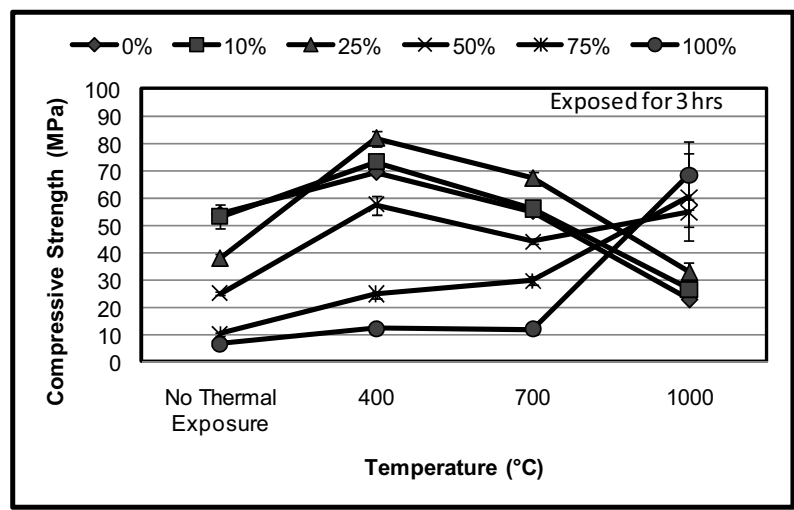

Figure 6. Effect of Thermal Exposure on Compressive Strength 


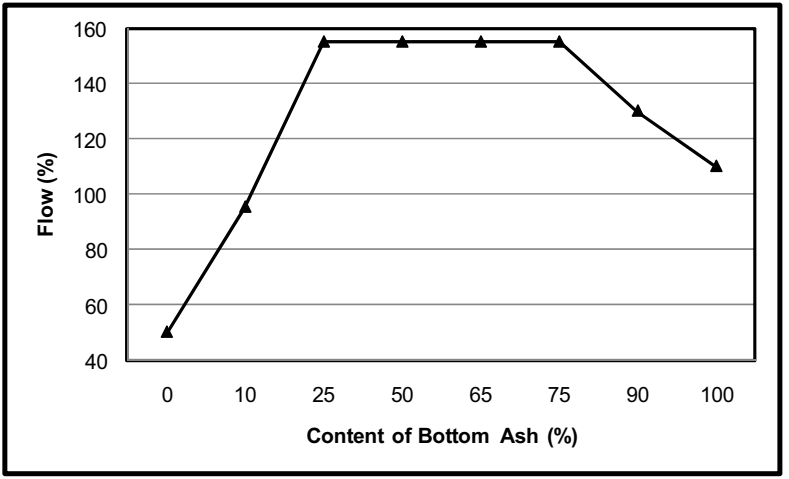

Figure 7. Effect of Content of Bottom Ash on Workability 